\title{
Complication rates for paediatric tonsillectomy based on Scottish national data 2000-2018
}

\author{
Christy Moen ${ }^{1}$, Laura Downie ${ }^{2}$, and Haytham Kubba ${ }^{1}$ \\ ${ }^{1}$ Royal Hospital for Children \\ ${ }^{2}$ Public Health Scotland
}

March 2, 2022

\begin{abstract}
It is important to give parents accurate information about complication rates as part of the process of informed consent for surgery. National, routinely-collected data give an opportunity to estimate the rates of rare adverse events such as bleeding, blood transfusion and death.

We reviewed data for all Scottish NHS hospitals over the time period 2000-2018 to identify all children (aged 0-16 years) undergoing tonsillectomy, and to identify adverse events occurring within 30 days of the procedure.

Readmission to hospital was required in $2 \%$.

Surgical arrest of haemorrhage was required in $1 \%$.

Blood transfusion occurred in $0.1 \%$ and death occurred in one child out of 50,194.
\end{abstract}

Abstract content goes here

\section{Hosted file}

Main.docx available at https://authorea.com/users/446484/articles/545694-complication-ratesfor-paediatric-tonsillectomy-based-on-scottish-national-data-2000-2018

\section{Hosted file}

Table 1.docx available at https://authorea.com/users/446484/articles/545694-complicationrates-for-paediatric-tonsillectomy-based-on-scottish-national-data-2000-2018

\section{Hosted file}

Figure 1.docx available at https://authorea.com/users/446484/articles/545694-complicationrates-for-paediatric-tonsillectomy-based-on-scottish-national-data-2000-2018 